\title{
THE EFFECTS OF META-DISCUSSION STRATEGIES TOWARD LOW ENGLISH PROFICIENCY STUDENTS IN ORAL ENGLISH PERFORMANCE
}

\author{
Saadiah Kummin ${ }^{1 *}$, Shahlan Surat', Ruslin Amir ${ }^{2}$, Maslawati Mohamad ${ }^{2}$ and \\ Melor Md Yunus
}

${ }^{1}$ CITRA Centre, Universiti Kebangsaan Malaysia, 43600 Bangi, Selangor, Malaysia

${ }^{2}$ Faculty of Education, Universiti Kebangsaan Malaysia, 43600 Bangi, Selangor, Malaysia

*Corresponding author: saadiah@ukm.edu.my

Publication date: 30 June 2020

To cite this article: Saadiah Kummin, Shahlan Surat, Ruslin Amir, Maslawati Mohamad, \& Melor Md Yunus. (2020). The effect of meta-discussion strategies toward low English proficiency students in oral English performance. Asia Pacific Journal of Educators and Education, 35(1), 75-91. https://doi.org/10.21315/apjee2020.35.1.5

To link to this article: https://doi.org/10.21315/apjee2020.35.1.5

\begin{abstract}
The ability to speak proficiently is very important among English as a second language (ESL) students. Educators should employ teaching approaches to make teaching and learning more effective. This paper discusses the effects of teaching meta-discussion strategies on low English profeciency students' achievement in oral English. This study used a quasi-experimental design using a non-equivalent control-group design. The sample population was 177 students comprising of 94 students in the experimental group and 83 students in the control group. The students in the experimental group were exposed to metadiscussion strategies for seven weeks under the guidance of two instructors. This study used the indicators of teaching and learning process questionnaire (InTLPQ) to measure the respondents' level of meta-cognitive awareness, meta-attention, meta-comprehension and meta-cognitive reflection. The independent variables in this study are meta-cognitive awareness, meta-attention and meta-comprehension. The data were analysed using descriptive and inferential statistics. The results of the MANOVA revealed that there was a statistically significant difference in the post-test score between the treatment and control groups with the value $p=0.00 ; p<0.01$. The Stepwise multiple regression analysis indicated both that the three independent variables are correlated and that they contributed positively to the achievement of the respondents' oral English. In conclusion, with constant practice of these strategies, students could enhance their oral ability by overcoming their weaknesses during the learning process.
\end{abstract}


Keywords: Meta-cognitive strategies, tertiary students, oral ability, English as a Second Language, independent learners

\section{INTRODUCTION}

At Universiti Kebangsaan Malaysia (UKM), it is compulsory for all undergraduate students to take English language courses. Starting with the 2015-2016 session, all undergraduate UKM students are required to have five credit hours of English before graduating. The English language courses offered by CITRA Centre UKM went through a restructuring in early 2015. New courses were introduced and now include the adopted communicative approach. The main emphasis of these courses is to enable the students to be able to communicate effectively. Being competent in communication involves not just production, but also interaction, which is clearly reflected in the Common European Framework of Reference for Languages (CEFR) treatment of speaking. This speaking component comprises of two skills: Production and interaction (Council of Europe 2001, 26). However, the students are evaluated not only on their oral skills but also on other language skills namely reading and writing. One of the new English language courses is Academic Communication I; only students who are weak in English (Malaysia University English Test (MUET) Band 2 or 3) enrol in this course. Due to their weak English proficiency level, these students obtained low or unsatisfactory results (Stapa, Tg Maasum, Mustaffa, \& Darus, 2008). Based on this, language educators are very concerned about students who are weak in English (Faridah, Maslawati, \& Sithaletchemy, 2016). Thus, a study was conducted by the English language educators to identify the factors that affect the weak students' poor performance in English. The findings indicate that the students' poor performance is due to two main factors: less interesting teaching approaches, and their negative attitude towards English. Indeed, the less interesting teaching approaches used in English lessons has resulted in students being passive and less interactive. It was found that some of them just wanted to complete this course and the other two courses to fulfil the requirement to graduate. This means that they believed that the ability to communicate in English effectively is not important, and so did not put much effort to score in the English courses. The findings of this previous research served as a springboard for the researchers to conduct this study.

In this study, the researchers attempted to identify the effects of meta-cognitive teaching strategies (meta-discussion strategies) in the teaching and learning of oral English skills. Meta-discussion strategies are typically used in the teaching and learning of the oral component (information sharing component) of language in order to enhance students' achievement in the language. The English educators 
hope that these strategies improve not only student communication skills, but also the quality of the learning process. The main objective of this course is to improve students' oral communication skills and help them develop their selfconfidence (Academic Communication 1 proforma). As stated in the course proforma, this course (Academic Communication 1) equips the students with the principles, techniques, strategy and appropriate language structure for effective communication. The main learning outcome is that students are able to apply their knowledge of communication and interaction in the English language through class activities including discussion, simulation, role-play and oral presentation (Academic Communication 1 proforma).

In this study, the intervention is the use of meta-discussion strategies in the information sharing component, which is an oral component in the Academic Communication 1 course. The information sharing component revolves around discussion skills. This component enables students to present their thoughts and opinions more effectively. The group discussion activities are also intended to help sharpen the students' critical thinking skills and generate students' ideas. This statement is supported by research by Johnston (1997), and Johnston, James, Lye, and McDonald (2000). Notably, many scholars believe that problem solving in collaborative learning is a practical approach (Ramsden, 1992; Maslawati et al., 2016). Indeed, according to Boud and Feletti (1991), a method of solving a problem on a collaborative basis can be defined as an approach involving a few students who discuss via face to face. Their discussion is meant to solve a problem assigned by their teacher and to promote students' independent learning (Maslawati et al., 2016). In addition, when students are engaged in teamwork activities, their level of motivation and confidence increases (Robblee, 1991). Studies by Ruddok (1978), Luker (1989), Griffiths, Houston and Lazenbatt (1996) and Maslawati and Shahizan (2014) show that students gain many benefits when working in a small group. Such activities enable the students to reflect and enhance their communication skills.

Meta-discussion includes the use of four meta-cognitive strategies: metaknowledge, meta-attention, meta-comprehension and meta-cognitive reflection and oral skills. The meta-cognitive skills are applied in the teaching and learning of oral skills to prepare students for the information sharing. This involves group discussion activities. Meta-discussion teaching strategies are employed to enhance the students' awareness about their own process of thinking and learning. This is in line with the goal of Malaysia's education system to produce students who possess high order thinking skills (Abdul Raof \& Sharifah Nor, 2000). Saemah, Zuria, Siti Fatimah, Ruslin and Khadijah $(2009 ; 2010)$ have proposed a module for educators. The module comprises of meta-cognitive strategies to be used as 
classroom activities. In this study, language instructors guide their students to use these meta-cognitive strategies prescribed in the module.

The purpose of this study is to investigate the effects of the meta-discussion strategies towards UKM students' achievement in English. Review of the literature was conducted to examine the empirical evidence on the effects of meta-discussion strategies in improving low English proficiency students' achievement in English. This study aimed to identify whether the meta-discussion strategies employed in Academic Communication I course improved the low English proficiency students' oral skills.

\section{LITERATURE REVIEW}

Meta-cognitive strategies are strategies that guide students to learn, develop personal goals, self-regulate and make modifications on task implementation or learning activities (Dunslosky \& Thiede 1998; Thiede, Anderson, \& Therriault, 2003). The meta-cognitive strategies could be further divided into four subcategories: Metacognitive awareness, meta-attention, meta-comprehension and meta-cognitive reflection.

Meta-cognitive awareness refers to the activities to plan, draft, revise or edit discussion process. During the discussion process, students receive two types of knowledge on the targeted language (Carr, 2010). The first is declarative knowledge (implicit or implied) and involves internalisation or absorption of language rules, such as definitions of words, and aspects of grammar and spelling. The second is the procedural knowledge. Procedural knowledge refers to the strategies and procedures used to process the information and language aspects in speaking. In the effort to continue the learning process of oral skills, learning moves from declarative knowledge to procedural knowledge until the performance of these skills becomes automatic.

Meta-attention involves activities that help students to be more focused on the learning process (Slavin, 1991; Woolfolk, 2004). At the initial stage, students should be able to identify the learning objective. This is followed by deliberate efforts to plan an action, and later monitor the achievement of the learning objective. Saemah et al. (2010) added that the implementation of meta-attention activities should be carried out at the beginning of the class when the teacher states the learning outcomes based on certain teaching unit. There are four stages under meta-attention: selection, acquisition, construction and integration (Weinstein \& Mayer, 1986). The selection and acquisition stage indicate how much has been 
learned. Students will concentrate on specific information, which is then transferred to long-term memory.

Meta-comprehension strategies refer to activities that involve deep processing as stated by Saemah et al. (2011). Meta-comprehension involves activities to plan, monitor and evaluate the construction of knowledge through deep approach and active learning strategies. Teachers guide the students to monitor and evaluate their progress by explicitly modelling the thinking process. Prompts and cues are used to encourage students to monitor their comprehension. The meta-comprehension phase involves the deep processing of the materials and the evaluation of understanding. This process involves meta-cognitive prompts that eventually train the students how to self-monitor and self-evaluate their own learning. This process should be discussed explicitly by the teacher. Eventually, the students develop relevant strategies and apply them during their lessons.

Meta-cognitive reflection is a reflection on one's cognition indicating a conscious effort on the part of teachers to guide students to think about how they learn (Beyer, 1987). He further explained that through the practice of meta-cognitive reflection, students will remember and reflect on their learning process that occurs. Meta-cognitive reflection helps students to be aware of the learning process. In this study, among the activities involved in the process of meta-cognitive reflection is to evaluate the achievement of students' learning outcomes and learning content (the content of Academic Communication 1 subject), and the process of learning how to learn (Saemah et al., 2010).

Meta-cognitive reflection practices will encourage students to self-reflect. Schon (1983) further added that personal reflection allows the students to identify the advantages and disadvantages of oral presentation. From their reflection, students design a follow-up action plan to improve the quality of learning. Furthermore, students can familiarise themselves with self-questioning. By carrying out selfreflection practices, students form a frame, reconstruct the frame, and design a new action plan on an ongoing basis.

The two types of knowledge needed by students to employ meta-cognitive strategies are: (1) procedural knowledge and (2) conditional knowledge. Procedural knowledge refers to the understanding on how to perform various cognitive activities, while conditional knowledge refers to knowledge of when and why to apply a strategy (Woolfolk, 2004). Beyer (1987) suggests that the use of reflection is to make learning process explicit. The experience helps students acquire the 'how to learn' skills; by applying these two types of knowledge, they are able to plan, monitor and evaluate their learning process more effectively. He further 
explained that the implementation of meta-cognitive strategies increases students' awareness on how to approach a learning situation. This approach provides students with opportunities to acquire and develop procedural and conditional knowledge.

\section{Related Past Studies}

Studies have shown that meta-cognitive strategies, even if administered in a short period of time, improve students' academic performance in English language learning. Cubukcu (2008) found that students who were taught meta-cognitive strategies over a five-week period achieved significantly better results than the control group. The results of his study have confirmed that reading comprehension could be much improved through systematic instruction using meta-cognitive language learning strategies.

The findings of many other studies also share similar results: students who are exposed to and apply meta-cognitive strategies in their learning process perform better in learning English (Ofodu \& Adepipe, 2011; Dülger, 2011; Saadiah \& Saemah, 2010; Taraban, Kerr, \& Rynearson, 2004; Vianty, 2007; Wafa, 2003; Wendy, 2010; Yang, 2009; Young \& Fry, 2008). Furthermore, a study conducted by Wafa (2003) indicated that the high achieving students who enrolled in specialised courses in English from An-Najah University in Palestine, used more meta-cognitive strategies compared to other learning strategies. This suggests that students with high achievement in English use more meta-cognitive strategies than students of low achievement. Her findings show that high achievers are highly aware of their needs and seek opportunities to practice English.

Ridley, Schutz, Glanz and Weinstein (1992) stated that meta-cognitive strategies help students navigate their learning activities and includes conscious monitoring, planning and selecting strategies, correcting errors, evaluating the effects of learning strategies and adapting appropriate learning behaviors and strategies. These students outperform others because they have a goal, which provides them with a motivating challenge. In addition, these students also possess meta-cognitive awareness, which helps them process information to accomplish their goal. Winn and Snyder (1996) stated that meta-cognition is important here because it involves one's ability to monitor one's own progress. Similarly, a pilot study conducted by Iza and Hani (2015) showed students who used meta-cognitive strategies yield positive results. This continues to support early work by Borkowski and Krause (1985) who proposed that when students are learning the content of a subject, meta-cognitive strategies should be developed, allowing students to identify their own strengths and weaknesses. This perception is further supported by Tomlinson 
and McTighe (2006) who argue that teachers should allow students to think clearly during the learning process.

Based on the above mentioned studies, it could be concluded that before giving the intervention most of these students show lack of knowledge on meta-cognitive strategies - knowledge to plan, monitor and evaluate themselves. In other words, they are not able to use appropriate strategies to perform a given task. The past studies have proven that by applying meta-cognitive strategies, students' learning process could be much improved.

As there are many studies highlighting the benefits of meta-cognitive strategies in language learning, the researchers believe that a study at our local institution (UKM) should be embarked. The objective of this study was to determine the effects of meta-cognitive awareness, meta-attention, meta-comprehension and meta-cognitive reflection towards low proficiency students' oral achievement.

\section{METHODOLOGY}

This is a quantitative study using quasi-experimental design.

\section{Participants}

The sample consisted of 177 students. The respondents were 94 students in the experimental group and 83 students in the control group. In the experimental group, students were given exposure to meta-cognitive strategies for seven weeks under the guidance of two instructors, while the control group was taught using conventional teaching approach. Before carrying out the intervention, both groups were given a pre-test to determine the consistency between the groups.

\section{Instrument}

The indicators of teaching and learning process questionnaire (InTLPQ) developed by Shahlan, Saemah, Zamri and Saadiah (2014) was used to measure the metacognitive awareness, meta-attention, meta-comprehension and meta-cognitive reflection. The oral performance was tested during the small group discussion evaluation conducted in the class. The data were analysed using descriptive and inferential statistics. The regression analysis involved four predictors: metacognitive awareness, meta-attention, meta-comprehension and meta-cognitive reflection, while the students' achievement in oral English was the criterion to the four independent variables. 


\section{The English Course}

All Year 1 UKM students who obtained MUET Band 2 and 3 enrol in an English (Academic Communication I). In this study, the focus was on the oral component of Academic Communication I (Information Sharing). The goal of the Information Sharing component is to enable students to share and exchange views in small group discussions on a certain issue. The issue is either a general or an academic issue. Prior to the evaluation, students were instructed to do some preparation individually as well as with their group members. Students had to read extensively on current issues related to general and academic topics. This step was to help the students to expand their vocabulary and general knowledge, recognise main ideas and important details, and able to express opinions on general and academic topics. Each of them was asked to find an article related to the topic or issue chosen by their group members. The students then prepared an outline of the article and presented it to their group members. Later, they discussed the issue being highlighted in their reading with their group members. Finally, the group concluded their discussion at the end of the session. The students carried out their discussions using appropriate language functions and discourse markers taught in the course.

The small group discussion provided opportunities for the students to express their opinions, state their points, pose questions and solve problems. This activity promoted the development of their oral skills. They also gave their feedback and reflected on the topic or problem that arose during the discussion. Both the practices and evaluation were carried out during the lessons under the language instructors' supervision.

\section{RESULTS AND DISCUSSION}

The main objective of the research is to determine whether meta-cognitive awareness, meta-attention, meta-comprehension and meta-cognitive reflection could contribute to the students' oral achievement when conducting small group discussions. The effectiveness was determined through the differences between the mean score of students in the experimental compared to the control group. The dependent variable was the performance in meta-discussion while the independent variable was the experimental and control groups. Table 1 presents the mean scores of the pre-test and post-test for both groups. The descriptive data show that the post-test for the treatment group is higher than the post-test of the control group. 
Table 1. Mean score for pre-test and post-test for the treatment and control groups

\begin{tabular}{lccccc}
\hline Strategy & & $N$ & Mean & SD & Mean Error \\
\hline Achievement & Groups treatment & 94 & 20.20 & 4.76 & 0.56 \\
in pre-test & Control & 83 & 20.25 & 6.12 & 0.59 \\
\multirow{2}{*}{ Achievement } & Groups treatment & 94 & 32.84 & 3.95 & 0.36 \\
in post-test & Control & 83 & 30.79 & 2.89 & 0.38 \\
\hline
\end{tabular}

In order to ensure the descriptive findings, whether the difference in mean score of oral performance is at significant level $p<0.01$, the MANOVA analysis was used in the Test of Between-Subject Effects. This could explain the results after controlling type 1 error by using the Bonferroni method. The findings show that there is a significant difference between the mean score for oral achievement between the experimental group and the control group with value $p=0.00, p<0.01$. The difference in mean score indicates the oral achievement of the experimental group is higher than the control group based on the post test (see Table 2). Therefore, the results of this study have successfully rejected the null hypotheses (there is no significant difference between the mean score of students' oral achievement, between the experimental group and the control group).

Table 2. Difference in mean score between groups

\begin{tabular}{|c|c|c|c|c|c|c|c|}
\hline \multirow{2}{*}{ Variable } & \multirow{2}{*}{$\begin{array}{c}\text { ( I ) } \\
\text { strategy }\end{array}$} & \multirow{2}{*}{$\begin{array}{c}(\mathrm{J}) \\
\text { strategy }\end{array}$} & \multirow{2}{*}{$\begin{array}{c}\text { Mean } \\
\text { diff. } \\
\text { I-J }\end{array}$} & \multirow{2}{*}{ Error } & \multirow{2}{*}{ Sig. } & \multicolumn{2}{|c|}{$\begin{array}{l}\text { Confidence } \\
\text { level 95\% }\end{array}$} \\
\hline & & & & & & $\begin{array}{c}\text { Lower } \\
\text { limit }\end{array}$ & $\begin{array}{c}\text { Upper } \\
\text { limit }\end{array}$ \\
\hline \multirow[t]{2}{*}{$\begin{array}{l}\text { Oral } \\
\text { Achievement }\end{array}$} & $\begin{array}{l}\text { Experimental } \\
\text { group }\end{array}$ & $\begin{array}{l}\text { Experimental } \\
\text { group }\end{array}$ & $2.05^{*}$ & 0.53 & 0.000 & 1.01 & 3.08 \\
\hline & Control group & Control group & $-2.05^{*}$ & 0.53 & 0.000 & -3.08 & -1.01 \\
\hline
\end{tabular}

Notes: Based on estimated marginal means; $*$ The mean difference is significant at the 0.05 level. a. Adjustment for multiple comparisons: Bonferroni.

The Stepwise multiple regression analysis is also used to identify the changes in two or more factors (independent variables) that contribute to changes in the dependent variable. Here, multiple regression analysis indicates the influence of two or more independent variables on a designated dependent variable (Bryman, 2008).

Before running the multiple regression analysis, several prerequisites such as sample size, multicollinearity and singularity, normality, homogeneity and linearity were met. The regression analysis involved the four predictors of meta-cognitive 
awareness, meta-attention, meta-comprehension and meta-cognitive reflection while variable achievement in oral English is a criterion to the four independent variables.

The $F$-test results show the relationship between the three predictor variables, metacognitive awareness, meta-attention, meta-comprehension on the significance level criterion variable, meta-comprehension $(F=94.48$ and sig. $=0.00<0.05)$, meta-cognitive awareness $(F=90.98$ and $\mathrm{sig}=0.00<0.05)$ and meta-attention $(F=66.46$ and sig. $=0.00<0.05)$. One variable, meta-cognitive reflection excluded or rejected from the regression. The contribution value of meta comprehension is $R^{2}=0.507$ and $\beta=0.36$, meta-cognitive awareness is $R^{2}=0.667$ and $\beta=0.39$ and meta-attention is $R^{2}=0.689$ and $\beta=0.25$.

Table 3. ANOVA. Independent variable and dependent variable variants

\begin{tabular}{llccccc}
\hline Model & & Sum of squares & Df & Mean squares & $F$ & Sig. \\
\hline 1 & Regression & 378.30 & 1.00 & 378.30 & 94.48 & 0.00 \\
& Residual & 368.39 & 92.00 & 4.00 & & \\
& Total & 746.69 & 93.00 & & & \\
2 & Regression & 497.75 & 2.00 & 248.88 & 90.98 & 0.00 \\
& Residual & 248.94 & 91.00 & 2.74 & & \\
3 & Total & 746.69 & 93.00 & & & \\
& Regression & 514.46 & 3.00 & 171.49 & 66.46 & 0.00 \\
& Residual & 232.23 & 90.00 & 2.58 & & \\
& Total & 746.69 & 93.00 & & & \\
\hline
\end{tabular}

Notes: Based on estimated marginal means; * The mean difference is significant at the 0.05 level. a. Predictors: (Constant), Post meta-comprehension. b. Predictors: (Constant), Post meta-comprehension, Post meta-cognitive awareness. c. Predictors: (Constant),), Post meta-comprehension, Post meta-cognitive awareness, Post metaattention. d. Dependent Variable: Post Oral

The results of the step by step (stepwise) multiple regression analysis has identified the relative contribution of four independent variables on the achievement of oral English, summarised in Table 3 . The findings show that three independent variables have contributed significantly $(p<0.05)$ in the total variance in achievement of oral English. The independent variables are meta-cognitive awareness, meta-cognitive comprehension and meta-attention. These variables contributed $68.9 \%$ to the variance in students' achievement in oral English. Therefore, the null hypothesis, which states there is no significant contribution by the independent variables on the achievement of oral English, is rejected. 
Table 4. Stepwise regression analysis for independent and dependents variables

\begin{tabular}{lccccc}
\hline Variables & $\mathrm{B}$ & Standard Error & Beta $(\beta)$ & $t$ & Sig. \\
\hline Variables & -2.68 & 2.83 & & -0.95 & 0.35 \\
Meta-comprehension & 2.39 & 0.64 & 0.36 & 3.72 & 0.00 \\
Meta-cognitive awareness & 4.99 & 0.83 & 0.39 & 6.00 & 0.00 \\
Meta-attention & 1.68 & 0.66 & 0.25 & 2.54 & 0.01 \\
\hline
\end{tabular}

Notes: Independent Variables: Post meta-comprehension, Post meta-cognitive awareness, Post meta-attention

\section{Dependent Variable: Post Oral}

These results show that the main predictor and the highest achievement in oral English is meta-cognitive comprehension $(\beta=0.36, t=3.72, p=0.000)$. This shows that for every one-unit increase in score of meta-cognitive comprehension, students' oral scores increased by 0.36 units. This finding shows that when there is an increase in the meta-cognitive comprehension aspects of teaching and learning, the level of oral performance also increased.

The second main predictor is meta-cognitive awareness $(\beta=0.39, t=6.00$, and $p=0.000)$. This means that when the meta-cognitive awareness increases by one unit, an increase of 0.39 units is shown in the oral performance. This finding clearly indicates that when there is an increase in meta-cognitive awareness among the students in the aspects of teaching and learning, the level of oral performance also increases.

The third main predictor is meta-cognitive attention $(\beta=0.25, t=2.55$, and $p=0.001)$. This means that when the meta-cognitive awareness increases by one unit, an increase of 0.25 units is indicated in the oral performance. This shows that when there is an increase in meta-cognitive attention, there is also an increase in the level of oral performance among the students.

The findings show that meta-cognitive comprehension, meta-cognitive awareness and meta-cognitive attention are predictors for an increase in achievement in an oral English post-test.

One of the important characteristics of expert learners is the ability to control their own learning (Saemah et al., 2010). Further, this process involves metaattention and meta-comprehension. The findings of this study indicate that these meta-cognitive strategies contribute to the students' better achievement 
in oral English evaluation. This explains that the high level of students' metacognitive awareness, meta-attention and meta-comprehension could enhance their ability to overcome their weaknesses in oral English.

In this study, during the teaching of meta-cognitive strategies in small group discussion process, meta-cognitive awareness, meta-attention and metacomprehension were greatly emphasised. The activities that were conducted included planning, writing, checking and editing the drafts of the discussion. These activities were carried out throughout the discussions and problem solving in small groups. The interventions of this study are similar with the use of strategies proposed by Nakatani (2010). According to her, meta-cognitive awareness, metaattention and meta-comprehension should be taught in the teaching process. Teachers should ensure that the students understand the content of the component taught, and students should take responsibility to monitor and reflect various steps involved in their own learning process.

The small group discussion began with the introduction to the component. This stage is important because it triggered the students' previous knowledge. The next stage was the group discussion whereby the students expressed their ideas and thoughts. The students discussed with their group members about the input they have learned. The students used various input that were included in the teaching module that they felt would benefit the group discussion. Students came up with examples derived from their extensive reading. Later, they practiced the discussion based on the sample task given by the language instructors. Based on the input given in the module, the students conducted a few conversation activities with their group members. The use of examples and input given in the module developed students' understanding on the component taught by the language instructor.

While conducting the small group discussions, the students performed the given task and monitored their own progress. They were encouraged to use the metacomprehension strategies. They constantly asked themselves questions either individually or with their group members to check their understanding on the component taught. As proposed by Nakatani (2010), students were encouraged to use the oral communication strategies taught during the planning, monitoring and evaluating when they completing their task. This is in line with Ridley et al. (1992) and Winn and Snyder's (1996) viewpoints. They stated that students who use meta-cognitive strategies could consciously control their own learning starting from the planning stage. This means that they are more likely to effectively engage in choosing the right strategies, monitoring their own progress and correcting errors, and evaluating the effectiveness of the strategies used. 
The English language instructors gave much attention to the process of obtaining information through procedural knowledge. While performing the meta-cognitive reflection activities, the students processed their learning by remembering and recalling the steps in the discussions. The high level of comprehension has contributed to the high achievement of students' in the oral skills. Here, meta-cognitive awareness played an important role in the students' achievement in oral English. Through active discussion among the group members and other members in other groups, it enhanced the students' meta-cognitive awareness in the learning process through planning, monitoring and evaluating. The group discussion activity similarly promoted the development of ideas in planning the discussion. Moreover, since the information sharing component in Academic Communication I course primarily focus on group discussion, students were able to interact and carry out the group discussion effectively. This study shows that the students' ability in teamwork resulted in improved performance on the student's oral skill achievement.

According to Baker and Brown (1984), meta-cognitive skills allow students to control the development of what he or she has learned to try and understand a new knowledge. The meta-cognitive strategies make students possess meta-cognitive awareness (when, how, and why the strategies are used). These strategies help students make better topic selections, plan the discussion, describe the contents of the material, and develop proper use of language functions and discourse markers. As a result, there is an increase in the students' performance level in oral English. Notably, this group discussion activity also encouraged students to be involved in the processing of information by guiding the students to choose the correct problem solving strategy, asking the students to discuss in groups, and asking students to explain the ways to solve the problems.

These findings support the belief that meta-cognitive strategies should be used by teachers to help students focus not only on the content of the subject but also on the learning process. The exposure and practice helps students acquire 'how to learn' skills, allowing them to take charge of their own learning. In the beginning, the use of scaffolding is needed to train students to develop their meta-cognitive strategies. However, the scaffolding should be lifted gradually when they have developed certain level of awareness. These strategies should be infused in the teaching and learning process to help students become expert learners. It is important to note, however, that there may be other factors affecting and influencing the performance of oral English that are not addressed in this study. 


\section{CONCLUSION}

This research proposes that meta-discussion strategies (meta-knowledge, metaattention, meta-comprehension) enable low proficiency students to improve their achievement in oral English. In addition, the meta-cognitive reflection also helps students learn skills that are beneficial for future use.

Meta-discussion strategies were also found to support the development of metaknowledge, cognitive regulation, meta-attention, and meta-cognitive reflection among students, which are important in the development of self-regulated learners. As a result, students become more competent in planning, monitoring and assessing their learning process, as well as in controlling their performances. It is therefore, highly recommended that English language educators apply these strategies during the process of teaching and learning. When students employ these learned meta-cognitive strategies, they display the ability to detect their weaknesses that arise in the learning process, which motivates them to improve. In particular, using meta-cognitive strategies in small group discussion enable the students to use the appropriate language functions and discourse markers. This suggests that it is essential for language instructors to work with students on becoming more effective learners by helping them to develop good meta-cognitive awareness and meta cognitive skills. Future studies should be directed towards developing a module that includes meta-discussion strategies to be applied in other subjects or courses in order to identify their effectiveness in other subjects.

\section{ACKNOWLEDGEMENTS}

This research has been funded under GG-2019-008 Dana Penyelidikan FPEND PTS-2014-012 Projek Tindakan/Strategik, Universiti Kebangsaan Malaysia.

\section{REFERENCES}

Abdul Raof Husin, \& Sharifah Nor Puteh. (2000). Penyemakan semula kurikulum untuk pendidikan alaf baru. Strategising Teaching and Learning In The 21st Century, $1,330-334$.

Baker, L., \& Brown, A. (1984). Meta-cognitive skill and reading. In P. D. Pearson (Ed.), Handbook of reading research (pp. 353-394). New York: Longman.

Beyer, B. K. (1987). Developing thinking skill program. New York: Allyn \& Bacon, Inc. 
Borkowski, J. G., \& Krause, A. J. (1985). Metacognition and attributional beliefs. In G. d'Ydewalle, (Ed.), Cognition, information processing, and motivation (pp. 557-567 ). North Holland: Elsevier Science Publishers.

Bryman, A. (2008). Social research methods (3rd ed.). New York: Oxford University Press.

Carr, M. (2010). A longitudinal study of the development of mathematics strategies and underlying counting schemes. International Journal of Science and Mathematics Education, 9(1), 1-24.

Council of Europe (2001). Common European framework of reference for languages: Learning, teaching, assessment. Cambridge: Cambridge University Press.

Cubukcu, F. (2008). Enhancing vocabulary development and reading comprehension through metacognitive strategies. Issues in Educational Research, 18(1), 1-11.

Dunslosky, J., \& Thiede, K. W. (1998). What makes people study more? An evaluation of factors that affect self-paced study. Acta Psychologica, 98, 37-56. https://doi. org/10.1016/S0001-6918(97)00051-6

Dülger, O. (2011). Meta-cognitive strategies in developing EFL writing skills. Contemporary Online Language Education Journal, 1(2), 82-100.

Faridah, M., Maslawati, M., \& Sithaletchemy, K. (2016). Developing workplace awareness through project work. Creative Education Journal, 7(1), 180-188.

Griffiths, S., Houston K \& Lazenbatt, A. (1996). Enhancing student learning through peer tutoring in higher education. Coleraine, Ireland: Ulster University.

Iza, N. I., \& Hani, S. A. (2015). Incorporation of meta-cognitive strategies in teaching writing to engineering students. Paper presented at Prosiding Persidangan Antarabangsa Kelestarian Insan kali ke-2, The Royale Bintang Resort \& Spa, Seremban, 19-20 October 2015.

Johnston, C.G. (1997). Collaborative learning of economics in a peer tutoring context at the University of Melbourne. Australian Economic Papers, September, 56-68.

Johnston, C. G., James, R. H., Lye, J. N., \& McDonald, I. M. (2000). An evaluation of collaborative problem solving for learning economics. Journal of Economic Education 31(1), 13-29.

Luker, P. (1989). Academic staff development in universities with special reference to small group teaching. Unpublished doctoral dissertation, University of Nottingham.

Maslawati, M., \& Shahizan, S. (2014). Online forum discussion to promote sense of learning community among the group members. International Education Studies, 7(13), 49-68. https://doi.org/10.5539/ies.v7n13p61

Maslawati M., Izyan Safwani I., Normilah W., Saripah M. (2016). Medical students' challenges and strategies in producing web TV programs on YouTube. Creative Education Journal, 7(4), 604-618. https://doi.org/10.4236/ce.2016.74063

Nakatani Y. (2010). Identifying strategies that facilitate EFL learners' oral communication: A classroom study using multiple data collection procedures. The Modern Language Journal, 94(1), 116-136.

Ofodu, G. O., \& Adedipe, T. H. (2011). Assessing ESL students' awareness and application of metacognitive strategies in comprehending academic materials. Journal of Emerging Trends in Educational Research and Policy Studies (JETERAPS) 2(5), 343-346. 
Ramsden, P. (1992). Learning to teach in higher education. London: Routledge.

Ridley, D. S., Schutz, P. A., Glanz, R. S., \& Weinstein, C. E. (1992). Self-regulated learning: The interactive influence of meta-cognitive awareness and goal-setting. Journal of Experimental Education, 60, 293-306. https://doi.org/10.1080/00220 973.1992.9943867

Robblee, K. M. (1991). Cooperative chemistry. The Science Teacher, 58(1), 20-23.

Ruddok, J. (1978). Learning through small group discussion. Guildford: Society for Research into Higher Education (SRHE)/University of Surrey.

Saadiah Kummin, \& Saemah Rahman. (2010). The relationship between the use of metacognitive strategies and achievement in English. Procedia Social and Behavioral Sciences, 7, 145-150. https://doi.org/10.1016/j.sbspro.2010.10.021

Saemah Rahman, Zuria Mahmod, Siti Fatimah Mohd Yassin, Ruslin Amir, \& Khadijah Wan Ilias. (2010). The development of expert learners in the classroom. Contemporary Issues in Educational Research, 3(6), 1-8. https://doi.org/10.19030/cier.v3i6.209

Saemah Rahman, Ruhizan M Yasin, Kamaruzaman Jusoff, Siti Fatimah Mohd Yassin, Ruslin Amir, Zuria Mahmod, Shahlan Surat, \& Saadiah Kunmin. (2011). Metacognitive strategies and expertise in learning. World Applied Sciences Journal, 13(4), 645-650.

Saemah Rahman, Siti Fatimah Mohd. Yassin, Zuria Mahmod, Ruslin Amir, \& Khadijah Wan Ilias. (2009). The development of expert learners from teachers and students perspectives. Paper read at EABR \& TLC Conference Proceedings at Prague Czech Republic.

Schon, D. (1983). The reflective practitioner: How professionals think in action. New York: Basic Books.

Shahlan, S., Saemah, R., Zamri, M., \& Saadiah, K. (2014). The use of meta-cognitive knowledge in essay writing among high school students. International Education Studies, 7(13), 212-218. https://doi.org/10.5539/ies.v7n13p212

Slavin, R. E. (1991). Are cooperative learning and un tracking harmful to the gifted? Response to Allan. Educational Leadership, 48(6), 68-71.

Stapa, S. H., Tg Maasum, T. A. R., Mustaffa, R., \& Darus, S. (2008). Workplace written literacy and its effect on the curriculum. GEMA Online Journal of Language Studies, 8(1), 23-33.

Taraban, R., Kerr, M. S., \& Rynearson, K. (2004). Analytic and pragmatic factors in college students' metacognitive reading strategies. Reading Psychology, 25, 1-15.

Thiede, K. W., Anderson, M. C., \& Therriault, D. (2003). Accuracy of meta-cognitive monitoring affects learning of texts. Journal of Educational Psychology, 95, 6673. https://doi.org/10.1037/0022-0663.95.1.66

Tomlinson, C. A., \& McTighe, J. (2006). Integrating differentiated instruction and understanding by design. Alexandria: Association for Supervision and Curriculum Development.

Vianty, M. (2007). The comparison of students' use of metacognitive reading strategies between reading in Bahasa Indonesia and in English. International Education Journal, 8(2), 449-460.

Wafa Ab Shmais. (2003). Language learning strategy use in Palestine. TESL-EJ, 7(2) (Online). 
Weinstein, C. E., \& Mayer, R. (1986). The teaching of learning strategies. In M. C. Wittrock (Ed.). Handbook of research on teaching (3rd ed., pp. 315-327). NewYork: Mcmillan.

Wendy, Y. K. L. (2010). Metacognitive strategy teaching in the ESL oral classroom. Australian Review of Applied Linguistics, 33(1), 02.1-02.19. https://doi. org/10.2104/aral1002

Winn, W., \& Snyder, D. (1996). Cognitive perspectives in psychology. In D. H. Jonassen (Ed.), Handbook for research for educational communications technology (pp. 112-142). New York: Simon and Schuster Macmillan.

Woolfolk. A. (2004). Educational psychology (9th ed.). United States of America: Pearson Education, Inc.

Yang, C. (2009). A study of metacognitve strategies employed by english listeners in an EFL setting. International Education Studies, 2(4), 134-139.

Young, A., \& Fry, J. D.. (2008). Metacognitive awareness and academic achievement in college. Journal of the Scholarship of Teaching and Learning, 8(2), 1-10. 